\title{
Front Matter: Volume 11417
}

, "Front Matter: Volume 11417," Proc. SPIE 11417, Cyber Sensing 2020, 1141701 (3 June 2020); doi: 10.1117/12.2572776

SPIE. Event: SPIE Defense + Commercial Sensing, 2020, Online Only 


\section{PROCEEDINGS OF SPIE}

\section{Cyber Sensing 2020}

Igor V. Ternovskiy

Peter Chin

Editors

27 April - 8 May 2020

Online Only, United States

Sponsored and Published by

SPIE 
The papers in this volume were part of the technical conference cited on the cover and title page. Papers were selected and subject to review by the editors and conference program committee. Some conference presentations may not be available for publication. Additional papers and presentation recordings may be available online in the SPIE Digital Library at SPIEDigitalLibrary.org.

The papers reflect the work and thoughts of the authors and are published herein as submitted. The publisher is not responsible for the validity of the information or for any outcomes resulting from reliance thereon.

Please use the following format to cite material from these proceedings:

Author(s), "Title of Paper," in Cyber Sensing 2020, edited by Igor V. Ternovskiy, Peter Chin, Proceedings of SPIE Vol. 11417 (SPIE, Bellingham, WA, 2020) Seven-digit Article CID Number.

ISSN: 0277-786X

ISSN: 1996-756X (electronic)

ISBN: 9781510636118

ISBN: 9781510636125 (electronic)

Published by

SPIE

P.O. Box 10, Bellingham, Washington 98227-0010 USA

Telephone +1 3606763290 (Pacific Time) · Fax +1 3606471445

SPIE.org

Copyright (C) 2020, Society of Photo-Optical Instrumentation Engineers.

Copying of material in this book for internal or personal use, or for the internal or personal use of specific clients, beyond the fair use provisions granted by the U.S. Copyright Law is authorized by SPIE subject to payment of copying fees. The Transactional Reporting Service base fee for this volume is $\$ 21.00$ per article (or portion thereof), which should be paid directly to the Copyright Clearance Center (CCC), 222 Rosewood Drive, Danvers, MA 01923. Payment may also be made electronically through CCC Online at copyright.com. Other copying for republication, resale, advertising or promotion, or any form of systematic or multiple reproduction of any material in this book is prohibited except with permission in writing from the publisher. The CCC fee code is 0277$786 \mathrm{X} / 20 / \$ 21.00$.

Printed in the United States of America by Curran Associates, Inc., under license from SPIE.

Publication of record for individual papers is online in the SPIE Digital Library.

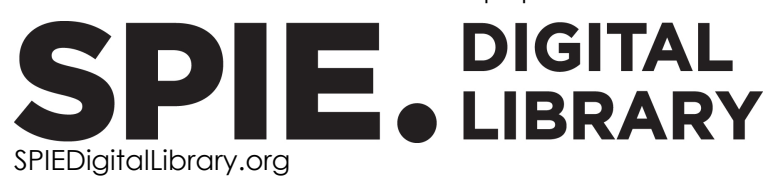

SPIEDigitalLibrary.org

Paper Numbering: Proceedings of SPIE follow an e-First publication model. A unique citation identifier (CID) number is assigned to each article at the time of publication. Utilization of CIDs allows articles to be fully citable as soon as they are published online, and connects the same identifier to all online and print versions of the publication. SPIE uses a seven-digit CID article numbering system structured as follows:

- The first five digits correspond to the SPIE volume number.

- The last two digits indicate publication order within the volume using a Base 36 numbering system employing both numerals and letters. These two-number sets start with 00, 01, 02, 03, 04, $05,06,07,08,09,0 A, 0 B \ldots 0 Z$, followed by 10-1Z, 20-2Z, etc. The CID Number appears on each page of the manuscript. 


\section{Contents}

\section{SESSION 1}

1141704 Experience with the CASPER system during RADICS field trials [11417-3]

SESSION 2

1141705 Remote attestation of host-based defense via optical channel [1 1417-4]

\section{SESSION 3}

1141709 A novel clustering technique using backscattering side channel for counterfeit IC detection [11417-10]

11417 OA Identifying class of previously unseen programs using RF side channels [11417-11]

11417 OB A robust principal component analysis approach to DoS-related network anomaly detection [11417-12]

\section{SESSION 4}

11417 OC Automated clustering of EM side-channel emissions to detect anomalous device behavior [11417-13]

11417 OD Program profiling based on Markov models and EM emanations [1 1417-14]

\section{SESSION 5}

$11417 \mathrm{OH} \quad$ Cybersecurity impact of the growth of data in sports [11417-18]

11417 J A new tool for detecting tampering of big data programs [11417-20] 
Proc. of SPIE Vol. 11417 1141701-4 Downloaded From: https://www.spiedigitallibrary.org/conference-proceedings-of-spie on 26 Apr 2023
Terms of Use: https://www.spiedigitallibrary.org/terms-of-use 